\title{
A Hokies' Lament: American Social Psychosis and the Virginia Tech Killings
}

\author{
Stephen Pfohl
}

"We are all Hokies!" read the freshly painted sign on the outfield wall of the Boston College baseball stadium, echoing a declaration of mourning made at Virginia Polytechnic Institute and State University following the terrible murders that took place there on April 16, 2007. I teach at Boston College. Like Virginia Tech, Boston College is a member of the Atlantic Coast Conference. And shortly after the Hokies' campus was drenched in blood, its baseball team journeyed north to play our school in a game charged with good will and far less tragedy than the violent game of life and death enacted in Blacksburg a few weeks previously. During the baseball game, in a prayerful memorial service, and on the pages of our university's newspaper, the phrase "We are all Hokies!" rippled across our campus for a time this spring.

A similar embrace of Hokie identity took place at other colleges and universities across the United States. And, like them, Boston College not only allied itself symbolically with the 32 students and faculty members gunned down in Blacksburg, it also took practical measures to guard against the possibility of a violent massacre taking place on its own campus in the future. Within weeks, the BC administration announced that it had invested in new technology, enabling campus police to instant message students within seconds, should it be learned that a killer is on the loose at our own school. Aside from this fearful contingency plan, what other lessons are to be learned from the terrible events that took place at Virginia Tech?

There is, of course, something moving about public identification with the victims of the Virginia Tech massacre and by widespread expressions of compassion for the families and loved ones, classmates and fellow faculty members, of those slain or wounded. In addition, in the weeks following the shootings both mainstream and new media outlets have taught their respective publics a great deal about the mixture of psychological, neurological, and environmental factors that leading experts view as contributing to the deadly actions of mass killers such as Cho Seung-Hui, the troubled Virginia Tech student and shooter. Time, for instance, quotes forensic psychologist Stanton Samenow, who notes, "They seem to have an unfathomable ability to shut off knowledge of the consequences, of the difference between right and wrong. It's critical for us to try to understand that worldview and its mental makeup."[1]

After concluding that mass violence typically combines "the dark hand of biology, life experiences, and the surrounding culture - plus the will to take lives in cold blood," Newsweek observes, "mass killers tend to be aggrieved, hurt, clinically depressed, socially isolated and, above all, paranoid. It is a specific kind of paranoia: a tendency to blame everyone but themselves for their troubles, to believe the world is against them and unfair.'[2] This, of course, fits the profile constructed by the media of Cho Seung-Hui, the isolated, angry, and depressed killer. In the digital video manifesto sent to NBC News, Cho declared, "You forced me into a corner and gave me only one option. The decision was yours. Now you have blood on your hands that will never wash off."[3]

Many media stories about the Virginia Tech massacre have provided information about the so-called "mind of a killer." Other than teaching educational institutions about how to better to look for warning signs, while bolstering technological defenses against sudden outbursts of psychotic violence-what societal lessons might we take from the killings in Blacksburg? Of immediate importance is increased public awareness of the need for tighter interstate regulation of firearms and the banishment for private purchase of such weapons as the Glock 19 semi-automatic handgun and the hollow point bullets Cho easily obtained from local gun stores and on the web. These are weapons 
of violence, not instruments of sport. But public awareness of the need for more effective gun control rises periodically, and then dissipates, following violent episodes such as that which took place at Virginia Tech. A spike in awareness and public outcry also occurred after the massacre at Columbine, but effective gun control remains legislatively derailed by powerful market forces and the corporately backed gun lobby. In addition, serious efforts to limit the availability of rapid-fire killing machines are hindered by populist social phantasms about the protection that deadly handguns and assault weapons can bring to law-abiding citizens. In the days following the shootings, conservative radio talk shows across America were replete with laments that more Virginia Tech students weren't carrying weapons. If they were, suggested fiery gun advocates, the killer would never have taken as many lives. Some other student would surely have taken Cho out before the killer completed his nightmarish rampage.

More complex questions about the wider social context of the killings arose in two lengthy discussions of the Virginia Tech murders in my undergraduate class on Deviance and Social Control. Prompted, in part, by a compelling mixed-media presentation by Mike Cermak, one of my graduate teaching assistants, on the effects of consumer electronics in everyday life, some students wondered whether the same technologies that so quickly place us in communication with others might also estrange or alienate us from each other. Does the quick communicative fix provided by contemporary consumer electronics serve only to deepen our connections to one another? Or do these new technologies also carry the danger of an increased instrumental objectification of others? Is it possible that the same high-speed electronic devices that put in us touch, also shorten our attention spans and make us less able to connect with people in face-to-face relations? Was the evermore-intense technological mediation of daily life a factor in the distance that Cho Seung-Hui felt from others? Were the cruel effects of the bullying that Cho had experienced in school and in church groups amplified during his college years by his relative exclusion from the omnipresent technological "friendship" networks of MySpace and Facebook?

What about the disconcerting phone calls Cho made to a frightened woman student two years before his deadly rampage, or the annoying instant messages he sent to another? What about the troubling cell phone calls he made to his roommate Andy Koch? Cho once called Andy to say that he was not himself but "Cho's brother, Question Mark." Later, over Thanksgiving break in 2005, Cho phoned to say he was vacationing with Vladmir Putin in North Carolina. "I am pretty sure that's not possible Seung," replied Andy.[4] What, moreover, are we to make of the fact that Cho had photographed the legs of female students from underneath their desks? Was this further evidence of his objectified distance from others, distance fostered by the increasingly technological orchestration of everyday life and death? Dense streams of technological connections and disconnections were in evidence everywhere in the media-relayed story of the Virginia Tech murders. From the cell phone camera that captured chaotic images and the sound of gunfire from nearby Norris Hall to the incessant repetition of these same frightening images and sound on television, to the multiple video blogs recounting students' terror, and, of course, the digital media show produced for our consumption by the killer himself, technology and the trail of violence went hand in hand at Virginia Tech.

Sparked by a provocative lecture given by Jared Del Rosso, another of my teaching assistants, students in my class also pursued questions about whether societal reactions to some of Cho's previous behaviors may have prompted him to identify with, or even respond in a perversely affirmative manner, to the fear expressed by others that he fit the stereotype of someone likely to be a school shooter. Did Cho feel hemmed in or, perhaps, even brazenly emboldened by the reactions of others to his often strange demeanor, menacing silence, and violent classroom writings? Were the worrisome labels applied to Cho by teachers, school administrators, mental health officials, and his fellow students "contributing factors" that hastened his precipitous slide into unimaginable violence? Was Cho acting out a terrible — but socially ordained—drama, scripted ahead of time by the way that others had pigeonholed him in the past?

Sociologists and anthropologists have long observed that dramatic acts of deviance can be occasioned-even called into being-by the collective anxieties of the society in which they occur. Such anxieties may be so vexing and unspeakable that they bear no proper name; at least not until a label connoting deviance is burnt into the identity of a condemned wrongdoer. In intensely unequal societies, such as our own-hierarchically organized societies founded on deep-seated material and psychic injustices and the structured exploitation of some classes, or classifications, of people by others - the deviant who is called upon to functionally embody what that society most abhors is also often a perverse, or monstrously mirrored, figuration of shameful aspects of what that society itself-or, more accurately, those most blessed by power in the society—would deny or disavow. Socially figured as evil—a cold blooded, emotionless, methodic, and empty-eyed killer-Cho Seung-Hui held up a psychotic mirror of mythic judgment to the society upon which he took aim. In the video message sent to us through NBC News, Cho declares, 
"You had everything you wanted. Your Mercedes wasn't enough, you brats. Your golden necklaces weren't enough, you snobs. Your trust fund wasn't enough. Your vodka and cognac weren't enough. All your debaucheries weren't enough. Those weren't enough to fulfill your hedonistic needs. You had everything."

Then came the crack of a $9 \mathrm{~mm}$, "the weapon of choice for cops and criminals, civilians and soldiers—and a sick young man in Virginia." [5] At first, most everyone thought it was the sound of construction, the erection of another university building, an architectural homage to global power and knowledge. Soon it was evident that this was the sound of something far worse - the sound of both a determined executioner and a symbolic message aimed at you and me. To treat Cho Seung-Hui's actions as bearing symbolic importance is not to romanticize or dignify Cho's violence. Cho was, after all, crazy. To explore the social symbolism of Cho's deadly rampage is, instead, to ask that we delve beneath the conscious surface of his psychotic actions and words, seeking in them symptomatic lessons about the way American society sets its social boundaries and how our society values some lives, while discounting others.

Several students in my class raised concerns about the possible effects of Cho's ethnic identity. As a native of South Korea, might Cho Seung-Hui's terrible deeds spur violence against Korean Americans and other Asians residing in the United States? This concern is of particular importance when set within the landscape of contemporary racialized privilege and a continuing global "coloniality of power." [6] Commenting on the relative ignorance of many Americans about our nation's decidedly contradictory history of involvement with Korea, one student even wondered whether the Virginia Tech murders might exacerbate existing tensions between the United States and North Korea. Despite the significance of such concerns, it is important to remember that, while born in South Korea, Cho spent his later childhood and young adult life in the United States, surrounded by the rituals of American culture and economic life. Cho was, in a sense, "trapped in a generational warp, neither quite Korean like his parents nor American like his peers. His parents turned to the church for help within his emotional problems, but he was bullied in his Christian youth group, especially by rich kids."[7] Other students commented on the role that gender socialization might have played in Cho's horrific violence. Some pointed to Cho's troubled relations with women, while others pointed to how sadistic aggression is often "naturalized" in men in our culture as a learned response to situations of emotional turmoil, vulnerability, and relative powerlessness.

At this point in our discussion, another student in the Deviance and Social Control class made a connection between Cho's violence and recent U.S. history, speculating about mass public denial of responsibility for the horrors of the Iraq war as a haunting social context for the Virginia Tech killings. Without minimizing the tragic deaths in Blacksburg, the student reminded our class that on the same day in which NBC News reported on Cho Seung-Hui's media manifesto, "bombs ravaged Baghdad in five horrific explosions ... killing at least 171 people in the deadliest day in the capital since the American-led security plan for the city took effect two months" earlier.[8] Nearly 230 people were killed or found dead in Iraq on that single day. Attention to the horror of these mass killings was, however, displaced by headline coverage of the Virginia Tech massacre. But more disturbing than this simple displacement may be the fact that virtually nowhere in the United States on that day, nor on any of the days following the 2003 American-led invasion and occupation of Iraq, have there been mass public expressions of grief and mourning even mildly approaching those produced by the terrible events at Virginia Tech. Why?

I suppose it can be argued that it is only natural for us to mourn the deaths of those whose lives we identify most with. But why, as a nation, are we so manifestly unable to publicly identify with the lives, and mourn the deaths, of the hundreds of thousands of Iraqis killed as a result of the preemptive warfare unleashed by our country against Iraq? As mentioned previously, when attempting to account for the psychotic violence of mass killers, Time magazine quotes a leading forensic expert who states, "They seem to have an unfathomable ability to shut off knowledge of the consequences, of the difference between right and wrong. It's critical for us to try to understand that worldview and its mental makeup." This quote strikes me as being as applicable to the collective worldview and mental makeup of the United States, as it may be to the individual mental makeup of a psychotic mass killer. Both the individual killer and the killer nation displays an ability to "shut off knowledge of the consequences" of one's violence.

The continuing Iraq war must be understood as a primary historical context by which to make mythic symbolic sense of Cho Seung Hui's horrific actions-the social psychosis of a nation engaged in an enormously violent, thoroughly illegal, and strategically unprovoked campaign of preemptive warfare, the formal justification of which is nothing short of paranoiac. This is a war brought about - much like Cho's preemptive attack on his teachers and classmates_-not to defend against actual acts of aggression, but by the manufacture of psychotic fear of a very specific kind - a tendency to blame everyone but ourselves!

In attempting to make sense of the paranoiac violence of mass killers, Newsweek quotes James Alan Fox, 
professor of criminal justice at Northeastern University. According to Fox, "They see others as being responsible for their problems; it's never their fault.'[9] In attempting to justify the Iraq war, officials in the Bush administration repeatedly display a related form of psychotic reasoning, blaming imagined demons for unleashing the terror of mass killings - nonexistent weapons of mass destruction, nonexistent connections between the 9/11 terrorist attacks and Saddam Hussein, nonexistent connections between $\mathrm{Al}$ Qaeda and the government of Iraq, and nonexistent attempts by Iraq to secure materials for nuclear weapons to carry out a supposed imminent attack the United States. Today the problem is said to be Iran. Tomorrow, perhaps, Syria or Sudan will be blamed.

Evoked as a moral guide to U.S. foreign policy and the "war against terror," the paranoiac "axis of evil" pictured by President George W. Bush is as flexible and subject to psychotic mutation as the viral vectors of fast capitalism upon which it parasites. Each exhibits ritual denial of the historical actualities of an ascendant global order of things set into motion by institutions of power and profit such as the International Monetary Fund, World Bank, and U.S. military. It's never our fault! It's never our responsibility! It's never the result of fast corporate capitalist interests! It's never the outcome of Northwestern geopolitical designs on the oil-rich territories of the Persian Gulf! To paraphrase Cho Seng-Hui's own paranoiac self-justification for righteous violence-it was their threats, not our historical actions that forced us into a corner and gave us but only one option. The decision was theirs. As such, it is them, and not us, that have blood on their hands that will never wash off.

The analogy I am here making between pathological individual and social expressions of psychosis is rooted in Teresa Brennan's (1993) discerning theoretical analysis of the confounding of imaginary psychic projections and the violent social history of modern capitalist/colonialist expressions of power (chap.1:9-10). Brennan traces social psychosis in the West from its psychic origins in a "foundational fantasy" that makes the ego of modern "Man" appear as if "self-contained," and destined to exert control over the fields of living energetic matter upon which it depends economically for sustenance and survival. A projective distortion of material actuality, this fantasy gains steam and is spread across the globe by the twin forces of modern technological domination and the speedy advance of fast capitalist practices of commodification. The result is a perilous aggressive fixing and depletion of natural energetic connections with others and the world. This represents a psychotic disconnection and divorce from reality, what Patricia Williams (1991) refers to as a malaise of "social amnesia" (p. 15).

For Canadian social theorist Arthur Kroker, the social psychosis depicted by Brennan assumes a distinctive American form, steeped in anxiety and resentment and justified in religious terms by a longstanding Puritan ideology. This is because "the [dominant] American mind has always oscillated between two extremes-between the "war spirit' and spirit of 'acedia' (Kroker 2007:23)." For Kroker, such oscillation is symptomatic of a "classically split consciousness veering between a raging 'war spirit' (which, as de Tocqueville noted set out to conquer the continental wilderness with a bible in one hand and an axe in the other); and panic fear (tempered by melancholy self doubt) concerning the imminent dissolution of the boundaries of the self" (Kroker 2007: 23). Social psychosis, social amnesia, and split consciousness - these are ways of describing the paranoiac culture of historical denial and preemptive warfare that enveloped the psyche of Cho Seung-Hui from the outside in.

This is not to claim that Cho's violence was simply caused by American culture. It is, however, to suggest that the nihilism of each represents a complex and disturbed mythic mirroring of the other. In his media manifesto Cho Seung-Hui both lashed out at and identified with the sacrificial religious spirit of American culture, condemning what he perceived as the hypocrisy of U.S. Christianity, while likening himself to the suffering Christ. In refusing to own up to, and make reparations for, the violence we have collectively unleashed in Iraq and elsewhere across the globe, and in refusing to reckon with the guilt-ridden realities of socially structured inequalities here at home, American society similarly lashes out with resentment at those it views as enemies. At the time, America dresses itself up in the imaginary garb of a god-like suffering servant. This is evidence of a profound social psychosis. But while leading experts on the psychology of aggression remain plagued by an inability to predict individual psychotic outbursts of violence, the same need not be true at a societal level.

The terrifying social forces that make all Americans complicit with mass killings abroad and aggressive inequality within the boundaries of our own country will not be curtailed by new technologies of control aimed at instant messaging us when killers are on the loose. We may all be Hokies. But, perhaps, we are also all Cho Seung-Hui. To shed this terrible killer side of our split collective consciousness, it is necessary to begin to disassemble the warring social order to which we contribute daily. This order is rooted in a relentless search for speedy profit and a paranoiac denial of responsibility for the violence engendered by our collective actions in history. Ending the unlawful occupation of Iraq will not instantly rid our country of the nihilistic social impulses that fuel psychotic 
outbursts of violence. But it may help, particularly if stopping the war is but a first step toward waging a renewed campaign of global justice and peace. But paranoid about secret killers among us, and afraid of our own historical shadows, it seems more likely that America will continue to deny the violent social psychosis that holds our entire country hostage to a culture of war. This is a tragedy that far exceeds that of the terrible Virginia Tech killings. This is a Hokies' lament.

\section{Endnotes}

1. Jeffrey Kluger, "Why They Kill," Time, Vol. 169, No. 18 (April 30, 2007):54.

2. Sharon Begley, with Anne Underwood and Mary Carmichael, "The Anatomy of Violence," Newsweek, Vol. CXLIX, No. 18 (April 30, 2007):43.

3. Excerpt from video message sent by Cho Seung-Hui's to NBC News. (http://www.cnn.com/2007/US/04/18/ vtech.shooting/index.html). Retrieved May 29, 2007.

4. These and other details pertaining to the Virginia Tech murders are available in the Wikipedia entry for Seung-Hui Cho (http://en.wikpedia.org/wiki/SeungHui_Cho). Retrieved May 29, 2007.

5. Jerry Adler, “Story of a Gun,” Newsweek, Vol. CXLIX, No. 18 (April 30, 2007):37.

6. The term "coloniality of power" is used by Peruvian sociologist Aníbal Quijano to suggest that no aspects of contemporary culture or economy are entirely free of the haunting shadows of colonialism and the complex ways that colonial formations of power impact upon virtually all social processes, from the social constitution of what counts as valid forms of knowledge to the meaning of such diverse matters as pleasure, pain, and subjective experience. See, for instance, Quijano (2000).

7. Evan Thomas, "Making of a Massacre," Newsweek, Vol. CXLIX, No. 18 (April 30, 2007):24.

8. Kirk Semple, "Bombs Rip Through Baghdad in Wave of Attacks, Killing 171," The New York Times, Vol. CLVI, No. 53, 919 (Thursday, April 19, 2007):1.

9. James Alan Fox, quoted in Sharon Begley, with Anne Underwood and Mary Carmichael, "The Anatomy of Violence," Newsweek, Vol. CXLIX, No. 18 (April 30, 2007):43.

\section{References}

Brennan, Teresa. 1993. History After Lacan. New Quijano, Aníbal. 2000. "Coloniality of Power, Ethnocentrism, York:Routledge. and Latin America," NEPANTLA, Vol. 1(3):533-580.

Kroker, Arthur. 2007. Born Again Ideology: Religion, Williams, Patricia. 1991. The Alchemy of Race and Rights: Technology and Terrorism. Victoria, Canada:CTheory Books/NWP.

Diary of a Law Professor. Cambridge, MA:Harvard University Press. 
